\title{
Strategia, struktura oraz działania marketingowe firmy Hoop S.A.
}

\section{Wstęp}

Wiek XXI określany jest jako era informatyczna (Drucker 2000), w nim bowiem będzie istniało ciągłe zapotrzebowanie na szybką $i$ wiarygodną informację. Konsumenci, przedsiębiorstwa, organizacje non-profit będą potrzebować uporządkowanej, relacyjnej i zintegrowanej informacji. Multiplikacja informacji w gospodarce jest następstwem (Pierścionek 2003):

- cech charakteryzujących współczesnych odbiorców, dostawców oraz konkurentów,

- wzrostu złożoności zarówno rynków zbytu, jak i dostawców i konkurentów,

- rozszerzania się zakresu działalności biznesowej przedsiębiorstw,

- rozszerzenia zarówno zakresu, jak i intensywności konkurencji.

Wzrost zapotrzebowania na informacje związany jest m.in. $\mathrm{z}$ otwarciem się gospodarek oraz ze wzrostem konkurencji, czego odbiciem jest wzrost indywidualizacji działań oraz rozbudowa powiqzań z odbiorcami (marketing relacji) (Pierścionek 2003).

Celem opracowania jest zaprezentowanie $\mathrm{w}$ formie studium przypadku strategii, struktury organizacyjnej i podejmowanych działań marketingowych, w tym w Internecie, spółki giełdowej należącej do 500 największych firm w Polsce z listy „Rzeczpospolitej”.

\section{Ogólna charakterystyka firmy}

Firma Hoop S.A. powstała w 1991 r., wówczas jeszcze jako firma „Syncrys" Sp. z o.o. (Prospekt emisyjny... 2003), rozpoczynając działalność produkcyjną w 1992 r. w Bielsku Podlaskim. W 1993 r. na podstawie uchwały Zgromadzenia Wspólników nazwa spółki została zmieniona na Hoop International Sp. z o.o. W 1997 r. firma przekształciła się w spółkę akcyjną (Hoop S.A.). 
W 2002 r. firma Hoop kupiła 50\% udziałów w spółce dystrybucyjnej Dom Handlowy Megapak sp. z o.o. z siedzibą w Rosji. Spółka ta ma za zadanie dystrybuować napoje pod marką „Hoop”, wodę mineralną pod nazwą „Arctic”, jak również napoje alkoholowe „Hooch” (na obszarze Rosji). W 2003 r. spółka Hoop S.A. zadebiutowała na Giełdzie Papierów Wartościowych w Warszawie (Prospekt emisyjny... 2003)'.

\section{Tabela 1}

Struktura własnościowa jednostek zależnych wchodzących w skład Grupy Kapitałowej firmy Hoop S.A.

\begin{tabular}{|l|c|c|c|c|}
\hline Nazwa firmy & Siedziba & $\begin{array}{c}\text { Rodzaj } \\
\text { działalności }\end{array}$ & $\begin{array}{c}\text { Udział } \\
\text { w kapitale } \\
\text { zakładowym } \\
\text { w\% }\end{array}$ & $\begin{array}{c}\text { Udział } \\
\text { w ogólnej } \\
\text { liczbie } \\
\text { głosów }\end{array}$ \\
\hline $\begin{array}{l}\text { Przedsiębiorstwo pro- } \\
\text { dukcji Wód Mineralnych } \\
\text { "Woda Grodziska" } \\
\text { Sp. z o.o. }\end{array}$ & $\begin{array}{c}\text { Grodzisk } \\
\text { Wielkopolski }\end{array}$ & $\begin{array}{c}\text { Dzierżawa } \\
\text { środków } \\
\text { trwałych }\end{array}$ & 99,81 & 99,81 \\
\hline $\begin{array}{l}\text { Dom Handlowy Mega- } \\
\text { pak Sp. z o.o. }\end{array}$ & $\begin{array}{c}\text { Widnoje } \\
\text { (Rosja) }\end{array}$ & $\begin{array}{c}\text { Dystrybucja } \\
\text { napojów }\end{array}$ & 50,00 & 50,00 \\
\hline
\end{tabular}

Źródło: Prospekt emisyjny akcji zwykłych na okaziciela Hoop Spółka Akcyjna, Warszawa 2003 , s. 2.

\section{Struktura organizacyjna firmy}

W strukturze organizacyjnej przedsiębiorstwa Hoop S.A. jest sześć dziatów, spośród których dwa działy (handlowy i marketingowy) podporządkowano bezpośrednio prezesowi zarządu, a pozostałe wiceprezesowi (rys. 1.).

Funkcje marketingowe ${ }^{2}$ oraz dotyczące rozwoju marketingu internetowego w firmie realizowane są przez:

\footnotetext{
${ }^{\mathrm{I}}$ Firma Hoop w 2004 r. była zakładem pracy chronionej, dlatego zobowiązana była dotychczas do zatrudniania osób niepełnosprawnych na poziomie co najmniej $40 \%$, w tym m.in. $10 \% \mathrm{za-}$ trudnionych musiały stanowić osoby zaliczone do znacznego lub umiarkowanego stopnia niepełnosprawności, albo co najmniej $30 \%$ niewidomych lub psychicznie chorych.

${ }^{2}$ Działaniami PR w firmie HOOP S.A. zajmuje się jedna osoba, która bezpośrednio współpracuje $\mathrm{z}$ zarządem spółki (w strukturze firmy brak jest osoby bezpośrednio odpowiedzialnej za działania o charakterze PR). W ograniczonym stopniu prowadzi ten rodzaj działań Dział Marketingu, w jego bowiem strukturze znajduje się, obok Działu Jakości Materiałów Produkcji, Działu Badania i Analiz (Internetu) oraz Działu Trade Marketingu, Dział Promocji (patrz: Struktura organizacyjna Hoop S.A. [w:] Prospekt emisyjny akcji zwykłych na okaziciela Hoop S.A., Warszawa 2003, s. 140-142).
} 
- Dział Marketingu, w ramach którego prowadzone są badania i analizy internetowe,

- Dział Administracyjno-Socjalny, w ramach którego przeprowadzane są m.in. studia z zakresu analiz rynkowych w Pracowni Badań Rynku, Promocji i Reklamy,

- Działu Finansów, w skład którego wchodzi m.in. Dział ds. Rozwoju i Funkcjonowania Systemów Informatycznych.

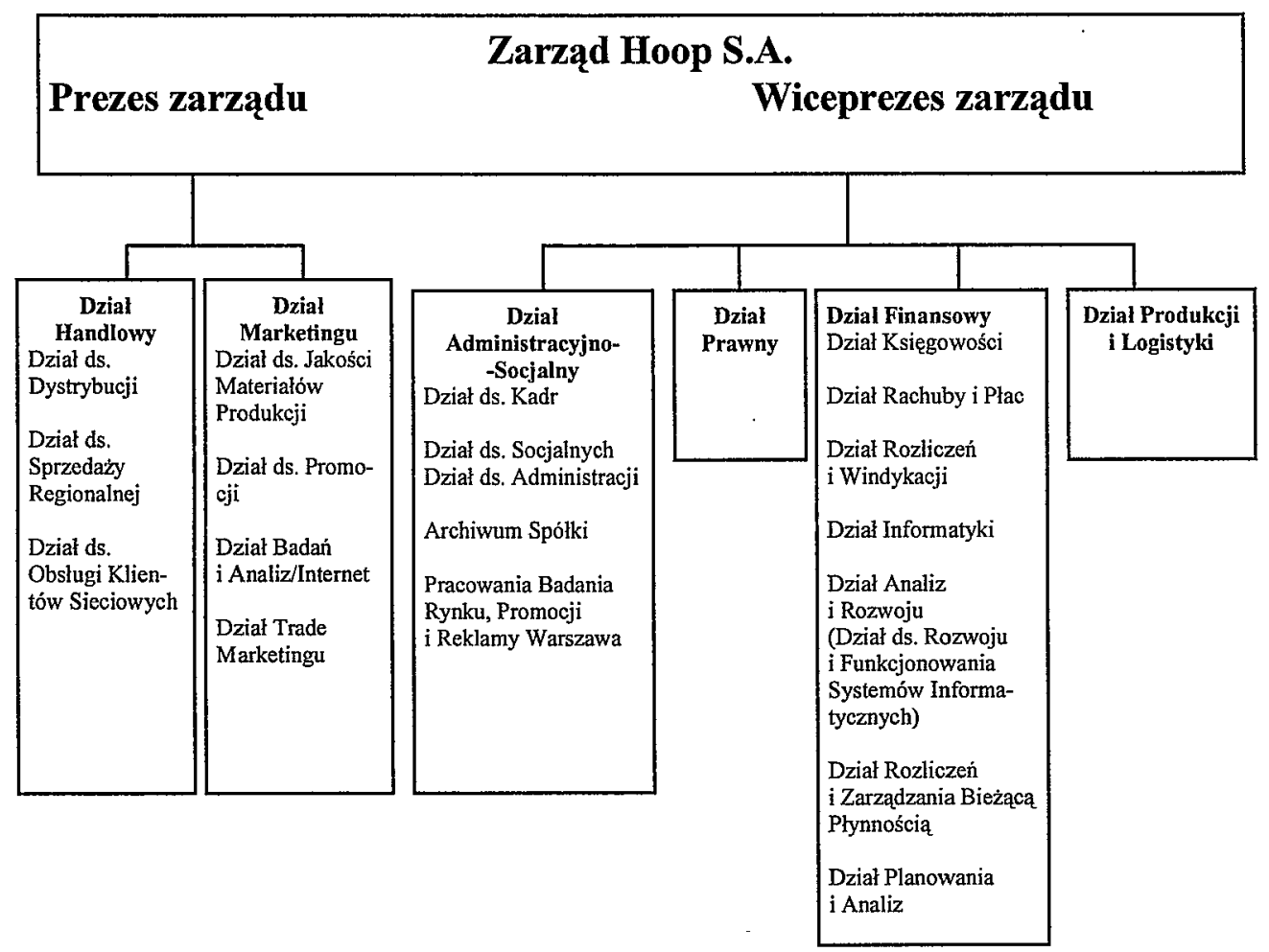

\section{Rysunek 1}

Schemat organizacyjny firmy Hoop S.A. w 2004 roku

Żródło: Prospekt emisyjny akcji zwykłych na okaziciela firmy Hoop S.A., Warszawa 2003 , s. 140.

\section{Strategia marketingowa firmy}

Strategia firmy Hoop S.A zakłada znaczqcy wzrost przychodów ze sprzedaży produktów, a co za tym idzie - uzyskanie silnej pozycji na krajowym ryn$k u$. Aby zrealizować wzrost sprzedaży, firma planuje zintensyfikowanie działań 
promocyjno-marketingowych oraz dalszq rozbudowe sieci dystrybucji i zwiększenie tym samym dostępności produktów firmy Hoop S.A. (Prospekt emisyjny... 2003), co równocześnie nie wyklucza akwizycji produktów innych producentów działających na polskim rynku. Celem działania władz spółki jest realizacja interesu spótki, rozumianego jako powiększenie wartości powierzonego jej przez akcjonariuszy majątku, $z$ uwzględnieniem praw $i$ interesów innych niż akcjonariusze podmiotów, zaangażowanych w funkcjonowanie spółki, w szczególności wierzycieli spótki oraz jej pracowników (Lad korporacyjny firmy 2004).

\section{Strategia marketingu internetowego}

Działania marketingowe $\mathrm{z}$ wykorzystaniem Internetu firma Hoop zaczęła realizować z chwilą założenia stron internetowych w $2003 \mathrm{r}$. Strategia działania firmy w sieci polega na budowie zaufania do wszystkich informacji umieszczanych na stronie - petnej, jasnej $i$ wartościowej informacji o firmie.

Firma korzysta m.in. $\mathrm{z}$ usług zewnętrznego przedsiębiorstwa, którym jest firma Interia (www.interia.pl). Firma ta zajmowała się dotychczas budową stron, ich formą graficzną oraz prowadziła serwisy produktowe (serwis korporacyjny firmy Hoop zarządzany jest przez pracownika firmy). Poza tym firma Hoop korzysta $z$ usług organizacji współuczestniczacych m.in. w kampaniach promocyjnych (outsourcing). Firmy te tworzą bazy danych osób uczestniczących w konkursach, a firma Hoop ma do nich dostęp.

Główną przyczyną powierzenia zadań związanych z zarządzaniem stronami produktowymi oraz działaniami promocyjnymi firmom zewnętrznym były, z jednej strony, niższe koszty, a z drugiej - większa ich fachowość.

\section{Ścieżka rozwoju marketingu internetowego}

Po raz pierwszy wykorzystano Internet w działaniach biznesowych w $1997 \mathrm{r}$. wówczas to została zaprezentowana pierwsza ogólna informacja o firmie początkowo w formie "wizytówki”, a od 2003 r. za pośrednictwem serwisu ogólnoproduktowego, skierowanego do konsumentów indywidualnych, w którym prezentowane są napoje (www.hoop.com.pl), serwisu korporacyjnego skierowanego do inwestorów i kontrahentów (www.firma.hoop.pl) oraz serwisu prezentującego pojedynczą markę (www.arctic.pl).

Zawartość graficzna stron internetowych została przebudowana w 2003 r. i zakłada się, że nie zostanie zmieniona w ciągu najbliższych 2 lat. Na stronach korporacyjnych firmy informacje umieszczone są w języku rosyjskim (firma działa już bowiem na tym rynku) oraz w języku angielskim, a w przyszłości będą $w$ języku niemieckim i holenderskim. 
Głównym motywem, dla którego firma zdecydowała się „wejść" w pełni do Internetu w 2003 r. był fakt, iż Internet staje się coraz bardziej popularną (powszechna) formą przekazu informacji, dającą m.in. możliwość usprawnienia komunikacji z konsumentami. Konsumenci w coraz większym stopniu wymagają rzetelnej (fachowej i szybkiej) informacji o produktach i firmie. Internet daje także możliwości przedstawienia się firmy Hoop jako czołowego producenta napojów i wzmocnienia swojego wizerunku. W związku z wejściem na Warszawską Giełdę Papierów Wartościowych (WGPW) firma została zobowiązana do prowadzenia serwisu korporacyjnego, w ramach którego publikowane są m.in. raporty bieżące, kwartalne oraz roczne, a także ważne informacje dotyczące sytuacji firmy. W 2003 r. wprowadzono nową stronę w technologii flash, dzięki czemu m.in. strona www.hoop.com.pl stała się w większym stopniu interaktywna. Od $2004 \mathrm{r}$. dostęp do sieci Internet mają wszystkie działy istniejące w strukturze przedsiębiorstwa. Dostęp do sieci umożliwia pracownikom bliższe kontakty $\mathrm{z}$ klientami oraz szybszy kontakt wewnątrz firmy przez intensywny przepływ informacji między pracownikami; gdy np., konsument wyrazi swoją opinie o wadach lub zaletach jakiegoś produktu, to jego list przesyłany jest bezpośrednio do technologa żywności.

Internet $w$ firmie Hoop jest najczęściej wykorzystywany jako narzędzie komunikowania się $\mathrm{z}$ konsumentami indywidualnymi za pośrednictwem poczty elektronicznej oraz przez „bramke" stworzoną na stronie produktowej firmy. $\mathrm{Z}$ inwestorami i kontrahentami firma najczęściej komunikuje się przez stronę korporacyjną firmy.

\section{Zintegrowany marketing internetowy ${ }^{3}$}

\section{Komunikacja marketingowa}

Konsument indywidualny dowiadywał się o istnieniu strony produktowej przede wszystkim $z$ informacji zawartych (wymienione wedhug rangi) na etykietach produktów, w gazetach reklamowych oraz z reklam emitowanych przed seansami kinowymi filmu „Władca pierścieni”. W trakcie tej reklamy prezentowany był również adres strony www, na której umieszczono regulamin konkursu. Dla podtrzymania kontaktów z konsumentami indywidualnymi przedsiębiorstwo wykorzystywało pocztę elektroniczna, SMSy oraz organizowało promocje i programy lojalnościowe.

\footnotetext{
${ }^{3}$ Wywiad przeprowadzony 29 września 2004 r. z Arkadiuszem Bielakiem, specjalista ds. prezentacji multimedialnych, który odpowiedzialny jest m.in. za zarządzanie stronami korporacyjnymi firmy Hoop S.A.
} 
Firma Hoop samodzielnie nie realizuje działań promocyjnych. Działania te zleca firmom zewnętrznym. Obsługa działań promocyjnych (m.in. regulaminy poszczególnych konkursów) prowadzona jest przez firmę Media-Net Interactive www.mni.pl. Promocja organizowana przez firmę MNI obejmowała osoby fizyczne, które kupiły produkt firmy Hoop oraz wysłały kod (SMSem), umieszczony na wewnętrznej stronie nakrętek. Promocją objęte były (od 24 listopada 2003 do 31 maja $2004 \mathrm{r}^{4}$ ) produkty z grupy napojów gazowanych premium (Cola, Tonic, Orange, Lemon, Limonka i Cytryna, czarna porzeczka o pojemności $0,51,1,51$ oraz 21 ). Chcąc uzyskać nagrody firmy Hoop, konsumenci musieli zebrać odpowiednio 8, 15 i 30 punktów za wysłanie SMSa, by uzyskać jeden $\mathrm{z}$ ufundowanych pierścieni (100 tys.), kubków (50 tys.) czy też plecaków z hologramem (5 tys.). Koszt wysłania SMSa wynosił 1,22 zł z VAT, przy czym uczestnik konkursu mógł wysłać nie więcej niż dwa kody, uzyskując za nie więcej niż 2 punkty. Nazwiska osób, które zdobyły nagrody, zostały umieszczone na stronie internetowej firmy Hoop (www.hoop.com.pl) oraz na stronie organizatora promocji (www.mni.pl).

Prowadząc działania promocyjne, firma Hoop umieszcza swoje banery reklamowe z podmiotami, z którymi współpracuje (jest sponsorem), np. w przypadku konkursu Miss Polonia czy też Oskar Mody.

Firma prowadzi aktywne działania promocyjne przede wszystkim w stosunku do wody mineralnej Arctic (www.arctic.pl). Woda ta jest najintensywniej promowanym produktem firmy, była ona promowana na stronach turnieju tenisowego „Polish Open” oraz konkursu Miss Polonia, gdzie firma była fundatorem głównej - nagrody samochodu marki Citroen. Promując markę Arctic, firma Hoop współpracuje zarówno z osobami, jak również z lokalnymi firmami, które zajmują się prowadzeniem zajęć fitness (klubami fitness). Współpraca ze strony firmy Hoop polega na promocji wody Arctic jako napoju dla osób aktywnych oraz dbających o zdrowy styl życia. Informacje o właściwościach tej wody umieszczane są na stronach klubów wraz z linkami do odpowiedniej strony produktowej firmy Hoop. Współpraca $z$ tymi firmami polega na zapewnianiu zarówno informacji o produkcie, jak i dostarczaniu wody Arctic do klubów.

Poza wymienionymi działaniami firma Hoop promując swoje napoje, ufundowała $\mathrm{m}$.in. bilety na koncerty Lenny Kravitza (amerykańskiego artysty rockowego), wzmacniając w ten sposób telewizyjną kampanię reklamową gdzie przewodnim hasło brzmiało „Czyw Kolumbii rozlewa się colę?".

\footnotetext{
${ }^{4}$ Pierwotny termin był do 30 marca 2004 r., patrz regulamin promocji pod tytułem „Hoop Zbierz Drużynę Pierścienia" umieszczony na stronie www.mni.pl
} 


\section{Produkt}

Głównym obszarem działalności firmy Hoop jest produkcja napojów (gazowanych, niegazowanych oraz wód mineralnych), spośród których najważniejszymi produktami firmy Hoop są napoje gazowane pod markami (Hoop Premium" (m.in. Hoop Cola - napój zawierający wyciąg z orzeszków cola oraz kofeinę, Hoop Premium Orange i inne), „Hoop” (takie napoje gazowane jak Tonic, Czerwona Oranżada, Biała Oranżada, Niebieska Oranżada), „Tyski Hoop" (Cola, Oranżada Czerwona, Oranżada Biała), „Mr Max” (Cola, Cytrynowy, Pomarańczowy oráz Oranżada Czerwona) oraz „3 Cole" (Strong Cola, Super Cola, Polska Cola) ${ }^{5}$. Niegazowane napoje pod marką „Hoop” produkowane są o smakach m.in. grejpfrutowym, pomarańczowym, marchewkowym, pod marka, „Hoopki" produkowane sa napoje skierowane do młodych konsumentów, pod marką "Hoop tea" produkowane są napoje herbaciane o smaku brzoskwiniowym i cytrynowym itp. (Prospekt emisyjny... 2003; wody mineralne to „Arctic" oraz „Woda Grodziska”.

W sieci Internet (na stronach produktowych firmy) znajduje się pełna oferta, jaka jest obecnie dostępna $w$ handlu hurtowym i detalicznym. Oferta jest aktualizowana, w sytuacjach gdy np. zostaje wprowadzony nowy produkt (np. oranżada o nowym smaku lub w nowym opakowaniu).

\section{Cena}

$\mathrm{Na}$ stronach Internetowych www.hoop.com.pl umieszczono informacje o produktach oferowanych przez firmę. Każda grupa produktów ma swoje graficzne odwzorowanie. Prezentowane są poszczególne rodzaje napojów (napoje gazowane, m.in. cola, cola light, orange, napoje niegazowane, „hoopki”, oranżady, inne), jak również podstawowe informacje odnoszące się do poszczególnych produktów, m.in. dotyczące zawartości w głównych składników; np. Hoop Cola zawiera (...) wyciag $z$ orzeszków. cola oraz kofeine pobudzajaco wpływajacq na ludzki organizm, a woda źródlana Gala prezentowana jest jako naturalna woda źródlana, która dzięki niewysokiej mineralizacji (...) w połaczeniu z lekko alkalicznym $p H$ i zawartościq rozpuszczalnych jonów wapnia $i$ magnezu, nadaje wodzie charakterystyczny orzeźwiajacy smak. (www.hoop.com.pl, 15 października 2004 r.). W ofercie firmy są również produkty, które przedstawia się jako napoje o dobrym smaku za niewielka cenę. Cena rynkowa napoju gazowanego Strong została ustalona na poziomie $1,90 \mathrm{zl}$. Napój ten jest produktem, jak zapewnia firma, o wysokich walorach smakowych, a równocześnie najtańszym oferowanym przez firmę.

\footnotetext{
${ }^{5}$ Poza wymienionymi napojami gazowanymi firma Hoop wytwarza napoje dla innych podmiotów gospodarczych pod markami Vivat, Aro, Volcano, Leader (patrz: Prospekt emisyjny akcji zwykłych na okaziciela Hoop Spółka Akcyjna, Warszawa 2003, s. 70).
} 


\section{Dystrybucja}

Podstawowymi kanałami dystrybucji, za pośrednictwem których firma dostarcza produkty na rynek, są duże, niezależne firmy dystrybucyjne, których udział w całkowitej sprzedaży wynosi $64 \%$, oraz wielkie sieci dystrybucji (sieci hipermarketów), których udział stanowi $36 \%$ całkowitej sprzedaży. Firma nie prowadzi sprzedaży za pośrednictwem Internetu.

\section{Działania wobec konsumenta}

Konsumenci indywidualni nie mają możliwości bezpośredniego kontaktu $z$ firmą. Jedyny przepływ informacji pomiędzy firmą a konsumentem odbywa się za pośrednictwem „bramki", a w przypadku inwestorów za pośrednictwem poczty elektronicznej lub klasycznej (gdy jest taka potrzeba). Charakterystyczne jest to, iż w firmie nie powstał dział obsługi klienta internetowego jako osobny dział $w$ strukturze firmy. Zadania te wykonuje jedna osoba $\mathrm{z}$ Działu Marketingu obok wielu innych zadań marketingowych.

Równocześnie przedsiębiorstwo nie gromadzi informacji o konsumentach indywidualnych. Jedyne informacje o konsumentach pochodzą z poczty elektronicznej. Przeciętnie od konsumentów indywidualnych przychodzi dziennie 20 listów zawierających sugestie, pytania, skargi lub wątpliwości.

Lojalność nabywców w „świecie rzeczywistym” wzmacniana jest jedynie przez organizowanie konkursów. W przypadku internetowych nabywców nie sa prowadzone jednak żadne działania, których celem byłoby wzmocnienie lojalności. Głównym sposobem budowy zaufania do witryny Internetowej (co ma również stanowić element wzmacniania lojalności) jest odpowiadanie na pocztę elektroniczną (docierającą na strony korporacyjne) oraz za pośrednictwem „bramki” (strony produktowe).

Firma Hoop kieruje część oferty (produkt Arctic) do osób aktywnych, uprawiających sport (nie ma to jednak „przełożenia" na dopasowanie informacji do potrzeb tej grupy odbiorców). Przedsiębiorstwo nie tworzy również marek oraz żadnej innej oferty skierowanej do społeczności internetowej. Kształtując swoją ofertę, firma Hoop S.A. nie podkreśla etnocentrycznego charakteru poszczególnych produktów. Wyjątkiem jest „Woda Grodziska”, pochodząca, jak się akcentuje, „z najczystszych terenów Polski”, czy też „Woda Gala”. W działaniach promocyjnych tych produktów firma nawiązuje do historii regionu.

\section{Relacje między marketingiem tradycyjnym i internetowym}

Marketing internetowy nie jest wyodrębnionym zadaniem. Jest on realizowany przez trzy osoby z różnych działów firmy (dyrektora Działu Marketingu oraz osobę z Działu Badania i Analiz (również Dział Marketingu), a także oso- 
bę z Działu Informatyki (Dział Finansowy). Relacje między tradycyjnym marketingiem i internetowym można określić jako „wzajemne wspieranie się", choć, jak się wydaje, w ,większym stopniu marketing tradycyjny wspiera Internetowy" niż odwrotnie.

Wspomaganie działalności w sieci realizowane jest przede wszystkim za pomocą działań promocyjnych (reklamy telewizyjnej, radiowej i prasowej). Firma wprowadza również programy, które mają za zadanie przyciągać klientów, m.in. „Wielka Loteria Arctic” oraz „Władca Pierścieni”.

By wspomóc marketing tradycyjny, firma Hoop prowadzi kontakt $\mathrm{z}$ internautami za pośrednictwem poczty elektronicznej (okienko poczty dostępne jest na stronie produktowej). Poza tym umieszczała banery na stronach współpracujących z nią firm. W przypadku „Władcy pierścieni” oraz Konkursu „Miss Polonia" banery spełniały jedynie funkcję informacyjną, kierując zainteresowanych informacją o sponsorze $\mathbf{i}$ jego produktami do stron produktowych firmy Hoop.

\section{Szanse i zagrożenia dla stosowania Internetu do marketingu}

Nie sposób określić skuteczności podejmowanych działań marketingowych w świecie wirtualnym, brak jest bowiem precyzyjnie określonych zadań stawianych $\mathrm{w}$ firmie Hoop przed marketingiem internetowym. Głównym zadaniem była przede wszystkim aktualizacja stron, by wzmocnić wizerunek firmy prezentując ją jako nowoczesna, ,idącą do przodu”. Szansą dla firmy jest wzmocnienie wizerunku przedsiębiorstwa jako firmy nowoczesnej, dysponujacej nowoczesnym serwisem internetowym. Zagrożenia dla prowadzonej działalności internetowej firmy postrzega się przede wszystkim w wymiarze technicznym (a więc w zagrożeniach, jakie niesie ze sobą ciagły rozwój narzędzi elektronicznych).

$\mathrm{Z}$ punktu widzenia firmy Hoop decyzja o podjęciu działań w Internecie jest oceniana jako słuszna, bowiem sprawiła że wprowadzono do firmy nowe technologie informatyczne, które przyczynią się zapewne do szybszego rozwoju firmy oraz stanowić będą „nowe narzędzie wsparcia dziatań marketingowych”.

\section{Podsumowanie i wnioskì}

Polskie przedsiębiorstwa coraz częściej stosują elektroniczne narzędzia do wspomagania zarządzania, wykorzystując zarówno Internet, Intranet, jak i Ekstranet, co będzie wpływać na strukturę wewnętrzną firmy i budowanie 
relacji z podmiotami ich rynkowego otoczenia. Wdrożenie Internetu w firmach będzie powodować wyłączanie poszczególnych funkcji poza firmę (outsourcing), przy jednoczesnym przekształcaniu się firm w wirtualne przedsiębiorstwa. Równocześnie technologie elektroniczne stwarzają dogodne warunki do rozbudowy zintegrowanych form organizacyjnych (struktury holdingowe, przedsiębiorstwa wielozakładowe itp). Implementacja Internetu w przedsiębiorstwach ma różny zakres i charakter. Może ona dotyczyć m.in. budowania związków $\mathrm{z}$ innymi podmiotami działającymi na rynku (B2B), a także działaniami marketingowymi 'skierowanymi do konsumentów indywidualnych (B2C).

W działaniach marketingowych firmy Hoop S.A. można dostrzec podejmowanie wysiłków zmierzających do upodobnienia asortymentu produktów do produktów znanych firm międzynarodowych (np. napoje gazowane Hoop Cola do Coca-Coli czy Pepsi-Coli, a wśród napojów niegazowanych Hoop Tea do Lipton Ice Tea czy do Nestea). Firma odwołuje się również do „legendy” lat 60 , produkując napoje typu oranżada. Ponadto, w działaniach marketingowych firma odwołuje się do charakteru lokalnego poszczególnych produktów („Tyski Hoop", woda mineralna „Woda Grodziska").

Rozwój zastosowania narzędzi informacyjnych (Intranetu i Internetu) w firmie Hoop utrudnia również fakt, iż brak jednoznacznej odpowiedzialności za działania marketingowe podejmowane w Internecie (marketing zewnętrzny). Poszczególne kompetencje dotyczące narzędzi informatycznych są rozdzielone na trzy działy, co, jak sądzę, w znacznym stopniu utrudnia implementację nowoczesnych technologii do podejmowanych działań marketingowych. W zakresie stosowanego marketingu internetowego firma nie wykorzystuje możliwości komunikacji z internautami, nie prowadzi bowiem ani akcji banerowych, ani akcji wysyłania poczty elektronicznej. Działania promocyjne (realizowane przez firmę zewnętrzna) są doraźne, nie wzmacniają relacji z konsumentem, a możliwości wysłania informacji przez „,bramkę" ze stron produktowych przez konsumentów są ograniczone choćby ilością tekstu, jaki można wysłać. Na tym tle lepiej wygląda budowanie relacji z inwestorami (którymi również mogą być konsumenci), ale jest zapewne wynik wejścia spółki na giełdę.

Nie sposób określić skuteczności podejmowanych działań marketingowych w świecie wirtualnym, brak bowiem było precyzyjnie określonych zadań stawianych przed marketingiem internetowym. A jedynym celem stawianym przez firmę było wzmocnienie wizerunku firmy, prezentując ją jako nowoczesna, ,idącą do przodu". I ten cel, jak się wydaje, został zrealizowany. 


\section{Streszczenie}

W artykule zaprezentowano strategię działania firmy Hoop S.A. (spółki z listy 500 największych firm w Polsce „Rzeczpospolitej”). Przedstawiono strukturę organizacyjną firmy w 2004 r., ścieżke rozwoju marketingu internetowego, a także podejmowane działania w zakresie zintegrowanego marketingu internetowego (komunikację marketingową, produkt, cenę, dystrybucję oraz działania wobec konsumenta). Na zakończenie zaprezentowano relacje między marketingiem tradycyjnym $\mathrm{i}$ internetowym oraz perspektywy zastosowania Internetu w działaniach marketingowych w przyszłości.

\section{Bibliografia}

DRUCKER P.F., Zarządzanie w XXI wieku. Wyd. Muza S.A., Warszawa 2000.

KOTLER PH., ARMSTRONG G., SAUDERS J., WONG V., Marketing. Podręcznik europejski. PWE, Warszawa 2002.

Ład korporacyjny firmy Hoop S.A. zamieszczony na stronie internetowej firmy www.firma.hoop.pl z 10 października 2004.

PIZLO W., Marketing internetowy relacji B2C. [w:] Agrobiznes 2003. Jakość jako podstawowy instrument konkurencyjności w agrobiznesie tom 2, red. nauk. S. Urban, Prace Naukowe nr 983. Wyd. AE im. O. Langego we Wrocławiu, Wrocław 2003.

PIZLO W., Przedsiębiorstwo w społeczeństwie informacyjnym. [w:] Uwarunkowania organizacyjne i ekonomiczne w aktywizacji społeczno-gospodarczej. Wpływ integracji europejskiej na przemiany strukturalne obszarów o wysokim bezrobociu. Wyd. Wydziału Ekonomiki i Organizacji Gospodarki Żywnościowej AR w Szczecinie, Szczecin 2003.

STRZYŻEWSKA M., Wpływ rynku internetowego i Internetu na rynek tradycyjny. [w:] Wykorzystanie Internetu w marketingu, pod red. nauk. E. Zeman-Miszewskiej, AE im. K. Adamieckiego w Katowicach, Katowice 2003.

Prospekt emisyjny akcji zwykłych na okaziciela Hoop Spółka Akcyjna, Warszawa 2003.

Regulamin promocji pod tytułem „Hoop - Zbierz Drużynę Pierścienia” umieszczony na stronie www.mni.pl

PIERŚCIONEK Z., Strategia konkurencji i rozwoju przedsiębiorstw, Wyd. Naukowe PWN, Warszawa 2003.

www.hoop.com.pl 


\title{
Strategy, Structure and Marketing Actions of the Firm Hoop S.A.
}

\begin{abstract}
The paper presents the use of the Internet in marketing actions of the enterprise Hoop S.A. In the paper organization structure of company in 2004, development of Internet marketing and action in integrated Internet marketing was showed. The relationship between classical marketing and Internet marketing and using Internet marketing in the future are also analyzed.
\end{abstract}

